\title{
Finding the common ground: phraseological theory and terminology revisited
}

\author{
Y. Kovalyuk \\ Yuriy Fedkovych Chernivtsi National University, 2, Kotsiubynsky St., Chernivtsi 58012, Ukraine
}

Paper received 01.01.18; Revised 06.01.18; Accepted for publication 08.01.18.

https://doi.org/10.31174/SEND-PH2018-149VI42-08

\begin{abstract}
The present paper is a state of the art review of the contemporary theory of phraseology. The field of phraseology has now been known to deal with 'the formulaic nature of language, the psycholinguistic reality of holistically stored multi-word expressions and the importance of phraseological units in second-language acquisition', among others [Hoffmann et al. 2015: 1]. Two major challenges, however, stand in the way: the ever-expanding list of terms pertaining to phraseology and a plethora of approaches regarding its scope. In an attempt to resolve these issues, the present paper will first focus on two major approaches to the study of phraseology: the traditional approach and the frequency-based approach. Then, a survey into phraseological terminology will be conducted. Further, connections between phraseology and four influential disciplines, i.e. construction grammar, semantics, pragmatics and cultural linguistics will be explored. It will finally be concluded with a discussion of the points under analysis.
\end{abstract}

Keywords: phraseology, construction grammar, semantics, pragmatics, cultural linguistics.

$\mathbf{1}^{1}$ Introduction. Phraseology has always been a tough nut to crack ever since Charles Bally, the founding father of phraseological theories, invoked the notions of fixed and loose phraseological units. According to the Cambridge Dictionary of Linguistics, phraseology refers to "the study of phrases, focusing on collocations and fixed expressions". Whereas Granger and Paquot argue that "phraseology has only recently begun to establish itself as a field in its own right" [Granger and Paquot 2008: 27], Zykova maintains that it has undergone three major stages - "the classical stage", "the non-classical stage", and "the post non-classical stage" [Zykova 2014: 110-115]. ${ }^{23}$

The present paper aims to bridge the theoretical and terminological gap in the contemporary theory of phraseology. The study is initially aimed at the description of the two principal approaches to phraseology: the traditional and the frequency-based. It will then examine the current terminological inventory in phraseology and identify major challenges herewith. In addition, spotlight will be put on the links between phraseology and four major disciplines: construction grammar, semantics, pragmatics and culture.

2 Major approaches to phraseology. In the last decade, the ongoing debate in the field of phraseology produced two principal approaches: 'the phraseological approach' and 'the frequency-based approach' [Nesselhauf 2004; Granger \& Paquot 2008]. The 'phraseological approach' is by default identified as a descriptive framework established in the Russian phraseology. The 'frequency-based approach', as its name suggests, has to do with the notions of 'frequency' and 'collocation' in corpora. Today, however, the above classification, in our humble opinion, does not completely reflect the true picture of phraseology and hence should be supplemented by a 'cognitive approach', a 'cultural approach' and an 'applied approach'. In other words, four main strands of research should be pinned down in the theory of phraseology: the traditional [the phraseological] strand, the cognitive strand, the cultural strand and the applied strand.

If we turn to the traditional approach, which by its mere

\footnotetext{
${ }^{1}$ This paper is based in part on work presented at the $7^{\text {th }}$ Formulaic Language Research Network (FLaRN), held at Vilnius University, 28-30 June 2016

${ }^{2}$ See also Teliya 1996 for a review.

${ }^{3}$ Such disparity is a matter of tradition: Zykova's account is largely entrenched in the Soviet scholarship drawing on the conceptions put forth by the likes of Vinogradov, Amosova, and Kunin, to name a few, whereas Granger and Paquot most likely refer to the foundation of The European Society of Phraseology (Europhras)
}

definition is rooted in the Russian phraseology, it becomes evident that it could be otherwise identified as "the traditional lexicological approach" [Gledhill 2011]. Howarth's [1996] characterization of the phraseological approach is one of the most cited [Granger \& Paquot 2008: 28; Laso and Salazar 2013: 6]:

it sees no watertight division between the various types of collocation and idiom, rather a continuum from, at one extreme, the most freely co-occurring lexical items and transparent combinations to, at the other, the most cast-iron and opaque idiomatic expressions. [Howarth 1996: 32]

Simplifying considerably, to make that continuum idiomatic expressions normally have to conform to three major characteristics: polylexicality [involving at least two lexical components], fixedness [stability of form, convention], and idiomaticity [semantic non-compositionality]. Albeit clearcut and well-defined at the first glance, these criteria prove plenty ambiguous if applied rigorously. In the first place, the polylexicality characteristic often falls into the trap of orthographic conventions, e.g. dead end and dead-end, which results in the cases in which "...linguists often make quite arbitrary decisions as to what they include and exclude" [Granger and Paquot 2008: 33]. Yet one possible rationale for the polylexical nature of phraseological units is its 'practicality' [Buerki 2016: 17]. As to the idiomaticity characteristic, traditional approaches tend to link it unequivocally to non-compositionality: "...the overall meaning is often not identical with the sum of the literal meanings of its constituents" [Jaki 2014: 10]. One issue with idiomaticity is that literal and figurative senses cannot be easily divorced from one another [Burger 2007; Wulff 2008; Philip 2011; Bybee 2013; Buerki 2016]. Moreover, idioms and idiomatic expressions, to say the least, seldom come fully non-compositional in discourse $e^{4}$, giving grounds to regard idiomaticity as a cline from the semantic standpoint. In cognitive linguistics, in an attempt to prove the point on the absolute semantic opacity or non-transparency of idioms wrong, some theorists [Langlotz 2006; Gibbs 2007 and others] have convincingly argued that they are not uniform attributes across the entire idiomatic repertoire of a language. In addition, today there is hard evidence that formulaic sequences, idioms among them, are processed quicker than their literal [non-formulaic] counterparts. L1 speakers and L2 [proficient] users do not have to first retrieve the literal meaning to then activate the idiomatic meaning of a sequence [Conklin and Schmitt 2008; Siyano-

\footnotetext{
${ }^{4}$ Fernando's case of pure idioms, semi-idioms, and literal idioms
} (Fernando 1996: 33-36) attests to that. 
va-Chanturia 2015]. Finally, as regards fixedness, it is traditionally argued that idiomatic expressions only allow for restricted variation [Langlotz 2006; Prodromou 2007; Jaki 2014], nevertheless corpus data show that variation is much commoner than some models suggest [Moon 1998: 7].

In contrast, where the phraseological approach had failed to gain ground, the "frequency-based approach" came in. Hence, with respect to the data driven approach, phraseology has been treated as "... the more abstract tendency for words to co-occur non-randomly and for the selection of particular lexical items to alter the probability of other lexical and grammatical choices" [Thompson and Hunston 2006: 10 ]." This view derives from Sinclair's "idiom principle" [1991], who, based on the previous studies of J. R. Firth and M. A. $\mathrm{K}$. Halliday, had put forth five criteria of idiomaticity for lexical items: semantic prosody and the invariable core [obligatory criteria], as well as semantic preference, collocation and colligation [alternative criteria]. The principle reads that "a language user has available to him a large number of semi-preconstructed phrases that constitute single choices, even though they might appear to be analyzable into segments" [Sinclair 1991: 110]. Essential preconditions for this principle to be put to work are "frequency and predictability of multiword units" [Siyanova-Chanturia \& Martinez 2014: 552]. Consequently, definitions of phraseological units within the frequency-based approach stand in stark contrast with those of the phraseological one: "co-occurrence of a form or a lemma of a lexical item and any other kind of linguistic element" [Gries 2008: 5]. As to corpus approaches to phraseology, they have been essentially twofold [Tognini-Bonelli 2001: 84-87]: corpus-based, with a focus on a pre-selected inventory of potentially relevant phraseological [multi-word] units [e.g., Moon 1998; Levin and Lindquist 2015], and corpus-driven, with corpus serving as a repository for the retrieval of a whole set of multi-word units under analysis [Biber 2009; Gray and Biber 2015].

3 Phraseology and terminology. The contemporary research in the area of phraseology is by all means manifold and so is its terminology. As a matter of fact, phraseology is no longer a "thing-in-itself", but rather an interdisciplinary phenomenon, with corpus linguistics, applied linguistics, cognitive linguistics, construction grammar, and formulaic language, to name a few, providing the backdrop for its current research.

The problem of terminology has already been given ample attention in [Barkema 1996; Cowie 1998: 1; Moon 1998: 1; Burger et al. 2007: 2; Granger \& Paquot 2008: 27; Naciscione 2010: 17, etc.], yet, given the recent developments in the field, a more rigorous account is needed. As Barkema [1996: 125] points out, "by adding a new set of terms to one which has become firmly established, one inevitably runs the risk of causing confusion where one intended to bring about clarity".

In traditional phraseology, idiom has always been the most comfortable term, at least in the Anglo-Saxon and American traditions [Nunberg et al. 1994; Fellbaum 2007, etc.]. In phraseological theory, the term has traditionally been applied with respect to its following meaning: "A speech form or an expression of a given language that is peculiar to itself grammatically or cannot be understood from the individual meanings of its elements" [OED]. Moon [1998], however, warns of potential perils concerning its narrower and broader senses. To avoid terminological bewilderment and lengthy discussions, some researchers [Gibbs 2007; Baranov and Dobrovolskij 2008] prefer to conform to a set of well-defined characteristics, e.g. compositeness, fixedness and idiomaticity, in their analyses of idioms in the narrow sense. A fresh look at the problem of idioms and idiomaticity was offered by Philip [2011]. The researcher argues that four defining criteria of idioms, such as compositionality/analysability, salience, semantic transparency, and adherence to truth conditions can make the difference when it comes to distinguishing between idiomatic [idioms and collocations] and non-idiomatic [lexical bundles] expressions. Again, these criteria are characterized as clines, inasmuch as pure idioms, like in the doghouse, are expected to exhibit all of them. On the other hand, phraseological unit is a good term that comes to rescue where idioms come short. Indeed, despite its proliferation in the Eastern European linguistics, it has been recently employed among a growing number of Western European researchers [Naciscione 2010; Jaki 2014; Rodríguez Martín 2014]. Take, for example, Kunin's definition: "a phraseological unit is a stable combination of words with a fully or partially figurative meaning" [1970: 210]. In terms of theoretical and practical applications, such structural definition could be good enough to account for the entire scope of phraseology: from nonphraseological word combinations to proverbs. Nonetheless, Anglophone researchers were [and still are] reluctant to embrace the term, nor is it to be codified by any major English language dictionary ${ }^{5}$. Phraseme is yet another term used outside British and American English linguistics [Mel'čuk 2015]. Burger et al. [2007: 3], however, advise against its superordinate use due to the suffix -eme, which puts a strong emphasis on the systemic aspect of figurative language units. It fares well with idioms, collocations and speech formulae, but should best not be used in a broader sense.

The corpus linguistics enterprise has bumped into a powerful ally in terms of phraseology to give rise to some important concepts otherwise overlooked by the mainstream approaches. First and foremost, the notion of collocation, which can be loosely defined as "...statistically significant co-occurrences of specific lexical items" [Fellbaum 2014: 777], has found itself in the limelight of corpus linguistics. Unlike the phraseological approach, which takes the view that collocations are grammatically determined word combinations [see for example Nesselhauf 2005], the term most often goes under the name of $\boldsymbol{n}$-grams [for alternative uses see lexical bundles, lexical chunks, clusters and lexical phrases] in corpus studies [Hoey 2005, Biber 2009, O'Donnell et al. 2012, and others]. N-grams [also known as bigrams and trigrams, depending on the number of words] are phrases or patterns of use characterized by frequent occurrence and contiguity of words like Would you like ...?, it follows that, etc. Skipgrams, as opposed to n-grams, stand for non-contiguous word associations, e.g. many believe vs. many people believe. Concgrams, for their part, were elaborated to compensate for the contiguity issues that arose with n-gram and skipgram analysis. Cheng, Greaves \& Warren [2006] define concgrams as follows: “a 'concgram' is all of the permutations of constituency variation and positional variation generated by the association of two or more words" [Cheng et al. 2006: 414]. In layman terms, what Cheng et al. argue is that concgrams allow for positional variation of words otherwise inaccessible with n-grams and skipgrams. Regarding multi-word units, the consensus holds among

\footnotetext{
${ }^{5}$ The dictionaries meant here are Oxford English Dictionary, Cambridge Advanced Learner's Dictionary, The American Heritage Dictionary and others.
} 
linguists that they are the best umbrella term for the extended units of meaning, n-grams, patterns, clusters, etc. included [Greaves and Warren 2012], whilst multi-word expressions is a coverall for all word combinations with varying degrees of idiomaticity and syntactic fixedness, e.g. idioms, prefabs, collocations, prefabricated chunks, etc. [Evert 2008, Hüning and Schlücker 2015].

As regards formulaic sequence, its original definition proposed by Wray [2002: 9] ${ }^{6}$ entails at least two important implications: first, the formulation such as "sequence, continuous or discontinuous, of words or other elements..." points, as Wray herself observes, to the broadest possible inclusion, where "other elements" most probably refer to what Wray later describes as "morpheme equivalent unit" [Wray 2008]; second, the wording such as "prefabricated" pertains to the processing of formulaic sequences as holistic units on the grounds that formulaic language is inherently psychological in nature [Hoey 2005]. Furthermore, formulaic language has now taken a firm hold in the lingua franca of applied linguistics [Wood 2015; Bardovi-Harlig and Stringer 2017] to represent all kinds of formulaic sequences?

4.1 Phraseology and construction grammar. For both structuralist and transformation-generative grammar accounts of language and linguistics, idioms were long seen as marginal and "anomalous" [Chafe 1968] linguistic phenomena. One possible rationale behind this is that idioms clearly depart from the traditional combinatory rules governing the formation of linguistic structures. The issue has grown in importance in light of recent developments in the theory of syntax, which all go under the name of Construction Grammar. This overarching family of approaches has proved compatible with idioms, and, most importantly, with the entire field of phraseology. One important tenet of Construction Grammar when applied to phraseology is that it licenses "no strict division between lexicon and syntax" [Goldberg 1995: 7]. Although it may sound pedestrian, constructions, at least by their definition ${ }^{8}$, are generally agreed to have much in common with idioms, most obviously in the department of non-compositionality. Herbst [2015: 92] describes the status of idioms in Construction Grammar as follows: "Idioms in the classical sense present a prototypical case of constructions". In the meantime, it is now more or less widely accepted that Construction Grammar is a theory that was and is being tailor-made for how idioms fit in the grammar of a language ${ }^{9}$. Nonetheless, from a broader perspective, the case on the apparent convergence between Construction Grammar as "the cognitive linguistic approach to syntax" [Croft and Cruse 2004: 225] and phraseology as "the tendency of words, and groups of words, to occur more frequently in some environments than in others" [a view adopted from Hunston 2011: 5] does seem to make sense today, given that idioms are no longer regarded as "complex lexemes" [Lipka 1992] and, most importantly, phraseology itself is seldom viewed as a branch of lexicology dealing with lexicon and lexical semantics of phraseological units, as advocated by

\footnotetext{
6 "a sequence, continuous or discontinuous, of words or other elements, which is, or appears to be, prefabricated: that is, stored and retrieved whole from memory at the time of use" Wray (2002: 9).

${ }^{7}$ See Wray (2002) and Siyanova-Chanturia (2015) for a review.

${ }^{8}$ I hereby refer to Goldberg's definition (Goldberg 1995: 4): 'Phrasal patterns are considered constructions if something about their form or meaning is not strictly predictable from the properties of their component parts or from other constructions'

${ }^{9}$ For a detailed discussion see Croft and Cruse (2004: 225); Wulff (2013: 274).
}

Dobrovol'skij [2016].

The now prevalent "usage-based approach" [Boas 2013: 176-183, Bybee 2013: 53-56; Perek 2015: 6-9, Diessel 2016: 296-300] argues for the convergence, rather than welldefined division, of grammar and usage on the one hand, and semantics and pragmatics on the other hand. This, in turn, results in taking the view that it is usage that determines grammar and not vice versa. Until quite recently, central to the entire discipline of phraseology was the premise that idioms, along with other fixed units [similes, proverbs, etc.] are relatively infrequent in language, as was convincingly proved in corpus-based studies by Moon [1998] and Grant [2005]. From the broader standpoint of usage-based construction grammar, however, it is quite the opposite, according to Hilpert [2014]:

...ordinary language is fully permeated by a large number of idiomatic expressions whose forms and meanings are not entirely predictable on the basis of either the word meanings recorded in a dictionary or the rules of syntax provided by a grammar. Hilpert [2014: 11]

The 'idiomatic expressions' presented in the analysis by Hilpert are as follows: in winter, coming into bloom, and as little as $0.5^{\circ} \mathrm{C}$. All three expressions mentioned manifest idiomaticity of some kind, however they are not idioms proper - hence the careful wording 'idiomatic expressions' by Hilpert. As a matter of fact, in winter is fully compositional and falls, most obviously, under the category of habitual collocations. As regards coming into bloom, this expression, which in Hilpert's terms 'would almost count as a real idiom' [2014: 10], is in fact an idiom of a 'semi-idiom' type [Fernando 1996]. In the case of as little as $0.5^{\circ} \mathrm{C}$, a comparative construction as...as is at work here. Yet what Hilpert is trying to convey is that it should be counted as an idiomatic expression only when used emphatically to denote 'the large amount/quantity', as in ...during the month of November as weather data shows that seas can reach as much as 10 meters in the Gulf of Alaska, or 'the small amount/quantity', as in ... a spark can happen at lightning speed and then as little as 90 seconds, etc. This indicates a need to raise a relevant question: are the uses of, say, as long as your arm and its literal counterpart idiomatic in the light of Hilpert's theory? The answer remains open to debate ${ }^{10}$, but what becomes apparent is that usage-based construction grammar is now pushing the boundaries of phraseology even further, largely through taking a fresh look at the compositionality and conventionality of constructions.

4.2 Phraseology and semantics. If there is one area central to the study of phraseology, it is semantics. In natural language semantics, the principle of compositionality is what lies at the heart of meaning construction. In phraseology, on the contrary, "lack of compositionality has indeed generally been considered an essential property of idioms and a good indicator of idiomaticity" [Vega Moreno 2007: 144]. Consider the following examples from The Corpus of Contemporary American English [COCA], which is virtually the largest corpus of American English currently available:

1. But Franklin, who grew up in Clarksville, stayed in her East Austin home, over time becoming the sole remaining member of the original group - the only person eligible to

\footnotetext{
${ }^{10}$ At face value, there seems to be a consent in the Construction Grammar theory that 'formulaic sequences' (Buerki 2016: 21), idioms including, are commensurate with 'the comparative correlative construction, particular clause types such as the passive, and fully productive grammatical patterns such as basic declarative sentences' (Diessel 2016: ).
} 
buy a house under the arrangement;

2. King takes pride in not screening calls but they're screened by his temperament, letting anyone bend his ear who comes calling hat in hand, posing flattering questions in fawning tones.

Naturally, the phrases to buy a house under the arrangement and bend his ear will end up in the opposing camps when scrutinized from the phraseological vantage point. It follows that to buy a house under the arrangement is fully compositional as the meanings of the individual words used add up to the overall [global] meaning of the phrase. Moreover, each of the words in the above phrase can be replaced by the appropriate synonymous equivalent, like to purchase a property under the contract, without damaging the meaning of the phrase to a greater extent. As evidenced from to bend one's ear, which by definition is an idiom, the substitution of any word, viz. flex for bend and ear for nose, will evidently lead to the loss of the idiomatic meaning and thus run counter to native-like selection. Language comprehension approaches have always favoured the literal/figurative dichotomy [Giora 1999; Beck \& Weber 2016]. Burger [2007] contends that describing and explaining if and how the literal and the figurative levels of meanings are connected is one of the main semantic problems in phraseology. As Philip [2011: 23] observes, "corpus linguistics copes with this fact rather well because its methodology is based on Firth's [1957] contextual theory of meaning; theoretical, philosophical, cognitive and psycholinguistics fare rather worse, because they consider context to be of secondary importance". One relatively recent solution to account for the problem was put forth by Giora [1997, 1999, 2003] in the form of the Graded Salience Hypothesis, according to which meaning is salient [is the first one to spring to mind] provided it had become part of the mental lexicon. Hence, the most important assumption made by Giora is that 'salient [e.g., conventional] interpretation has unconditional priority over less salient [e.g., novel] interpretation: the salient meaning of a word or an utterance is always activated' [Giora 1997: 186]. This claim is diametrically opposed to the traditional pragmatic model which prioritizes literal meaning activation, contrary to non-literal meaning. It follows that in the Graded Salience Hypothesis the figurative/literal divide gives way to the salient/non-salient split. In one of the recent attempts to put the Graded Salience Hypothesis to test, Cies'licka et al. [2014] in a study of idiomatic language processing found evidence of literal salience preference, although not consistent, for Spanish-dominant vs. English-dominant bilinguals. In a similar fashion, the Graded Salience Hypothesis was found only partially compatible with English-dominant bilinguals, showing that the figurative meanings of idioms were at times more easily activated than literal ones.

Theoretical [traditional] approaches put a special emphasis on such secondary meaning dimension as connotation. Connotations are speaker's attitudes, associations and nondescriptive meanings attached to a word or phrase, e.g. hand implies the act of giving, help, control, involvement, availability, close proximity, responsibility, etc. In this connection, the semantics of a phraseological unit was regarded to comprise several components: denotative, grammatical, emotive, stylistic, cultural, etc. [Teliya 1996; Vasilenko 2011]. Corpus-inspired studies, instead, argue for the concept of semantic prosody ${ }^{11}$, most notably in the works of Partington [2013,

\footnotetext{
${ }^{11}$ Partington's 'essentialist dualistic, bi-dimensional sense of 'the indication of whether the speaker thinks that something (a person, thing, action, event, situation, idea, etc.) is good or bad' (Partington 2014: 279)
}

2014], Hunston [2007], Bednarek [2008] and others. In simplest terms, semantic prosody stands for 'positive/negative connotation as well as more complex attitudinal connotations, affecting both single words and larger units of meaning such as phrases' [Bednarek 2008: 132]. The semantic prosodies of set in, sit through, undergo, budge, persistence/persistent, break out, outbreak, end up, cause, fuel, true feelings, etc. have been among the most frequently discussed in the literature. It is against the background of corpus-based studies in the field of phraseology that Levin \& Lindquist [2013], for example, have explored the semantics of ADVl constructions, like again and again and over and over. Based on historical and synchronic corpus data, they have found that such combinations tend to establish negative semantic prosodies over time. By a similar token, Partington and colleagues have observed, for instance, that, as evidenced from SiBol newspaper corpus, the word orchestrate, albeit having a positive meaning "combine harmoniously like instruments in an orchestra" [OED] at first glance, tends to develop highly negative semantic prosodies in discourse, i.e. "covert, secretive engineering of something apparently spontaneous for strategic purposes" [Partington et al. 2013: 89-90]. Closely related to semantic prosody, yet quite distinct from it, is the concept of semantic association [Hoey 2005]. In its essence, semantic association "exists when a word or word sequence is associated in the mind of a language user with a semantic set or class, some members of which are also collocates for that user" [Hoey 2005: 24]. To exemplify, Schönefeld [2013] has explored the intertwining nature of semantic prosody and semantic association by looking at the verbs go, come, and run. In the case of the verb go, it was found that its depictive uses 'mainly report unexpected states predicated of the [moving] subject, which are often felt to be negative [unnoticed, unchallenged], whereas adjunct uses of go strongly attract one negative collexeme [wrong] [Schönefeld 2013: 228].

4.3 Phraseology and pragmatics. A brief survey into the main fora of pragmatic research ${ }^{12}$ in search of phraseological, not to mention formulaic, accounts of language is always going to be next to fruitless. As befits any far-side pragmatics model, which is focused on what is said-what is conveyed perspective, it will rather disregard than deal with phraseological units of any kind. Tables turn, however, with the claim made by Erman and Warren [2000] that corpus texts are good 50\% prefabricated language. Of all the areas, Intercultural Pragmatics [Kecskes 2013] and the usage-based approach [Colston 2015] have evidently managed to put phraseology in the limelight of pragmatics. For Intercultural Pragmatics phraseology is part and parcel of "pragmatic competence, reflections of native-like behavior and often expresses cultural values, social expectations, and speaker attitude' [Kecskes 2013: 105]. Consider the following passage from COCA:

3. Kate also regularly travels for paid speaking engagements and has authored two books about life with multiples. Yet it's just this success, Kate says now, that has driven a

of semantic prosody is manifest in the terminology employed in his latter works (Partington et al. 2013, Partington 2014), whereby 'semantic prosody' is abandoned in favor of 'evaluative prosody'. Hunston (2007), for her part, criticizes such approach, inasmuch as 'treating evaluative meaning as a simple distinction between 'good' and 'bad' can be over-simplistic' (Hunston 2007: 267).

${ }^{12}$ For instance, The Oxford Handbook of Pragmatics 2017, Introduction to Pragmatics 2012, latest volumes of Journal of Pragmatics, International Review of Pragmatics and others. 
wedge into her marriage. 'I have always made more money than Jon, 'she explains. 'That doesn't bother me at all; it all goes into the same pot. But it obviously, at this point, really matters to him. He hates to speak, he doesn't write, he doesn't do public appearances--all those things I love. And now he's resenting me for it. My point is I could care less if this all died tomorrow, for my sake. It's for my kids. I feel if we put ourselves out there, it's got to be worth it, for them. For a while I was saying we're not just on different pages, we're in different books. But now I think we're in different libraries. [COCA]

At face value, the text piece is quite ordinary and typical of contemporary media discourse. That said, a second inspection, however, exposes the fact that it is literally imbued with the finest examples of English phraseology aplenty. Easily recognizable are idioms like to drive a wedge, couldn't care less, on the same page, speech formulae such as my point is that, for my sake, lexical bundles such as I feel if we, for a while I was, but now I think and even metaphorical expressions like in different books and in different libraries. All these are part of shared linguistic knowledge. For non-native speakers, nonetheless, they might be something of an unknown quantity. And this is where pragmatic competence comes into play. To illustrate, take the phrase I could care less. Quite surprisingly, it owes its provenance to $I$ couldn't care less "used to say, often rudely, that you do not think that sb/sth is important or worth worrying about" [OED]. I could care less, on the other hand, means "that one still has care left to give". What it comes down to is that native speakers of English often elect to replace the former [i.e., I couldn't care less] with the latter [i.e., I could care less], which is exactly the case in the quoted passage. For a non-native speaker, who is not well-versed in linguistic creativity, and from the standpoint of Intercultural Pragmatics, the what is said-what is conveyed view does not apparently hold, since the mechanism of psychological salience [the exposure to and the interpretation of the phrase in the appropriate context] may not come into operation. One more case of linguistic creativity evidenced from the passage above is the use of a modified idiom on different pages [the canonical form reads on the same page]. Hence, a question arises: how is a non-native speaker able to appreciate the precise meaning in the context? Colston [2015] suggests that common ground is what defines the successful use and comprehension of idioms. Meanings of transparent idioms are relatively easy to arrive at. When it comes to opaque idioms, their successful comprehension "would seem to depend on hearers having learned those meanings in some cultural context" [Colston 2015: 113]. Let us consider the following taken from Kecskes [Kecskes 2013: 110]:

4. LEE: Could you sign this document for me, please?

CLERK: Come again ... ?

LEE: Why should I come again? I am here now.

This exchange between Lee [Korean student] and a clerk at the Registrar's office is an illustrative example of the above points discussed. What is obvious from the piece of conversation is that the student has failed to initially establish the common ground with the existing linguistic community. Having encountered the idiom for the first time and shy of relevant cultural experience, he resorted to the literal interpretation of the phrase. As a result, no successful idiom comprehension was in place.

4.4 Phraseology and culture. Having briefly touched upon the issue of culture in phraseology, we cannot forgo it in the present paper, given the recent eponymous hefty vol- ume edited by Skandera [2007] and the Europhras conference held in Maribor [2012], along with other developments in the field. The cultural element in phraseology is frequently undervalued because it can give the impression that "phraseological units generally have an idiosyncratic structure or meaning" [Gledhill 2011: 9]. True, if you come across wordings as follows: "Phraseological semantics can play a key role in representing axiological relations as bedrock of national linguistic culture..." [Georgieva 2016: 92, my translation]. This brings us to the fundamental question: what are phraseology and culture all about? Lee [2007] provides the answer in part:

Conventional ways of saying things are subtle indices of cultural preoccupations and values, subtle because their automatic, routine, habitual nature renders them largely out of awareness for members of the culture, just as any other routine behavioural pattern, socially acquired in the course of enculturation, may remain out of awareness until violated in some way by cultural rebels, visitors or novices. The ability to reproduce and participate in strongly entrenched patterns of cultural behaviour, whether these be realized in the form of relatively ephemeral social markers or trends persistent across generations, is fundamental to being recognized as a member of any social group [Lee 2007: 471].

Evidently, this view is consonant with what was laid out in the previous section [Remember the awkward situation the Korean student found himself in?] and comes down to the fact the combination of phraseology and culture matters in cross-cultural communication rather than in mundane and routine situations, members of culture having more important business to attend to.

Linguists, meanwhile, have been trying to bridge the cultural gap in phraseology. Wierzbicka [2009, 2010] argues for the term collocational construction as a new analytical concept and a new conceptual tool in looking at English collocations with sense, such as a deep sense of shame, a sharp sense of relief and a deep sense of embarrassment. In an attempt to substantiate Locke's idea that 'knowledge is ultimately dependent on the senses', she maintains that "this idea has not been absorbed by other European cultures to anything like the extent to which it has been absorbed by Anglo culture" [Wierzbicka 2009: 114]. Kovshova [2012] is a description of Russian phraseological units from a linguistic-cultural perspective. The researcher developed a linguistic-cultural method in phraseology, aimed at the description of the role of phraseological units in linguistic conceptualisation. It is claimed that phraseological units both belong to figurative language and embed symbols, stereotypes, icons and mythologemes, thus acting as cultural markers. In another major study, Manca [2010] compared the phraseology of tourism in English and Italian. The findings confirm the initial hypothesis that the British and the Italians use different forms of promotion. As regards the British corpus, texts are rather "content-oriented", i.e. containing detailed and explicit information. In the case of the Italian corpus, the texts are "form-oriented", aiming to "create a fairytale aura and a dream atmosphere around the holiday in order to let people know that this holiday is really different from their everyday life" [Manca 2010: 119].

Conclusions. The present paper has followed in the footsteps of Wray [2002] and Granger and Paquot [2008] in describing what has been earlier referred to as 'the fuzzy borders of phraseology' [Granger and Paquot 2008: 29], construction grammar, semantics, pragmatics and culture in the limelight herein. The study conducted calls for the fol- 
lowing conclusions.

For one, the recent rise of the formulaic dimension in phraseology cannot be neglected. This, in turn, should manifest itself in the fundamental terminology employed. Therefore, we propose to supplement the conventional division of approaches to phraseology, i.e. 'the phraseological approach' and the 'frequency-based approach' [Nesselhauf, 2004; Granger and Paquot, 2008], with 'the formulaic approach' [Wray 2002, 2008; Wood 2015]. This, in our view, will help account for the production, comprehension and acquisition of phraseological units, largely beyond the scope of the phraseological approach and the frequency-based approach.

Secondly, taking into consideration that phraseology is now more interdisciplinary than ever, it seems reasonable to suggest that when dealing with the Pandora's box of phra- seological terminology one should go about descriptively rather than prescriptively over the matter. From the broader vantage point of interdisciplinary phraseology, claims that, say, 'phraseological unit', 'formulaic sequence' or 'multiword expression' should fill the role a superordinate term in phraseology seem overrated.

Thirdly, as Buerki [2016] puts it, 'as the importance of non-idiomatic formulaic sequences was increasingly recognised, new models of the relationship to the rest of linguistic knowledge surfaced [Buerki 2016: 21].' The herein explored links between phraseology and construction grammar, semantics, pragmatics and culture attest to that fact, yet we do recognize that the job done is only akin to that of a tip of an iceberg. Hence, provided further bridges are crossed in this respect, this paper has served its purpose.

\section{REFERENCES}

1. Baranov, Anatolij N. \& Dmitrij Dobrovol'skij. 2008. Aspekty teorii frazeologii. Moscow: Znak.

2. Bardovi-Harlig, Kathleen \& David Stringer. 2017. Unconventional expressions: Productive syntax in the L2 acquisition of formulaic language. Second Language Research. 33[1]. 61-90.

3. Barkema, Henk. 1996. Idiomaticity and terminology: A multidimensional descriptive model. Studia Linguistica 50 [2]. 125-160.

4. Bednarek, Monika. 2008. Semantic preference and semantic prosody re-examined. Corpus Linguistics and Linguistic Theory 4 [2]. 119-139.

5. Biber, Douglas. 2009. A corpus-driven approach to formulaic language: Multi-word patterns in speech and writing. International Journal of Corpus Linguistics 14. 275-311.

6. Boas, Hans C. 2013. Cognitive construction grammar. In Thomas Hoffmann \& Graeme Trousdale [eds.], Oxford handbook of construction grammar, 233-252. Oxford: Oxford University Press.

7. Buerki, Andreas. 2016. Formulaic sequences: a drop in the ocean of constructions or something more significant? European Journal of English Studies 20 [1]. 15-34.

8. Burger, Harald. 2007. Semantic aspects of phrasemes. In Harald Burger, Dmitrij Dobrovol'skij, Peter Kühn \& Neal R. Norrick [eds.], Phraseologie/ Phraseology. Ein internationales Handbuch zeitgenössischer Forschung / An international handbook of contemporary research, 90-109. Berlin \& New York: Mouton de Gruyter.

9. Bybee, Joan L. 2013. Usage-based theory and exemplar representations of constructions. In Thomas Hoffmann \& Graeme Trousdale [eds.], Oxford handbook of construction grammar, 49-69. Oxford: Oxford University Press.

10. Chafe, Wallace L. 1968. Idiomaticity as an anomaly in Chomskyan paradigm. Foundations of Language 4 [2]. 109-127.

11. Cheng, Winnie, Chris Greaves \& Martin Warren. 2006. From ngram to skipgram to concgram. International Journal of Corpus Linguistics 11 [4]. 411-433.

12. Cies'licka, Anna B., Roberto R. Heredia \& Marc Olivares. 2014. It's all in the eyes: how language dominance, salience, and context affect eye movements during idiomatic language processing. In Mirosław Pawlak \& Larissa Aronin [eds.], Essential topics in applied linguistics and multilingualism, 21-41. Berlin: Springer.

13. Colston, Herbert L. 2015. Using figurative language. New York: Cambridge University Press.

14. Conklin, Kathy \& Norbert Schmitt. 2008. Formulaic sequences: are they processed more quickly than nonformulaic language by native and nonnative speakers? Applied Linguistics 29 [1]. 72-89.

15. Cowie, Anthony P. 1998. Phraseology: Theory, analysis, and applications. Oxford: Oxford University Press.

16. Croft, William \& D. Alan Cruse. 2004. Cognitive Linguistics. Cambridge: Cambridge University Press.

17. Diessel, Holger. 2016. Usage-based construction grammar. In Ewa Dabrowska \& Dagmar Divjak [eds.], Handbook of cognitive linguistics, 296-322. Berlin \& New York: Mouton de Gruyter.

18. Dobrovol'skij, Dmitrij. 2016. Constructions grammar and phraseology. Voprosy Yazykoznaniya 3. 7-21.

19. Evert, Stefan. 2008. Corpora and collocations. In Anke Lüdeling \&

Merja Kytö [eds.], Corpus linguistics: an international handbook, Vol. 2, 1212-1248. Berlin \& New York: Mouton de Gruyter.

20. Fellbaum, Christiane. 2014. The syntax and grammar of idioms. In Tibor Kiss \& Artemis Alexiadou [eds.], Handbook of syntax, 776-802. Berlin \& New York: Mouton de Gruyter.

21. Fernando, Chitra. [1996]. Idioms and idiomaticity. Oxford: Oxford University Press.

22. Georgieva, Stefka I. 2016. Narodnaya kul'tura v zerkale kognitivnoy frazeologii. In Elena Ogneva, Elena Ozerova, Kira Stebunova \& Irina Chumak-Zhun [eds.], Kognitivno-diskursivnyye strategii razvitiya yazyka, 92-96. Belgorod: Epitsentr.

23. Gibbs, Raymond W. 2007. Idioms and formulaic language. In Dirk Geeraerts \& Hubert Cuyckens [eds.], The Oxford handbook of cognitive linguistics, 697-726. New York: Oxford University Press.

24. Giora, Rachel. 1997. Understanding figurative and literal language: The graded salience hypothesis. Cognitive Linguistics 8 [3]. 183-206.

25. Gledhill, Cristopher. 2011. The 'lexicogrammar' approach to analysing phraseology and collocation in ESP texts. Asp la revue du GERAS 59. 5-23.

26. Goldberg, Adele. 1995. Constructions: A Construction Grammar Approach to Argument Structure. Chicago: University of Chicago Press.

27. Granger, Sylviane \& Magali Paquot. 2008. Disentangling the phraseological web. In Sylviane Granger \& Fanny Meunier [eds.], Phraseology: An interdisciplinary perspective, 27-51. Amsterdam \& Philadelphia: John Benjamins.

28. Grant, Lynn. 2005. Frequency of 'core idioms' in the British National Corpus [BNC]. International Journal of Corpus Linguistics 10 [4]. 429-451.

29. Gray, Bethany \& Douglas Biber. 2015. Phraseology. In Douglas Biber \& Randy Reppen [eds.], The Cambridge handbook of English corpus linguistics, 125-145. Cambridge: Cambridge University Press.

30. Greaves Chris \& Martin Warren. 2012. What can a corpus tell us about multi-word units? In Anne O'Keeffe \& Michael McCarthy [eds.], The Routledge handbook of corpus linguistics, 212-226. London: Routledge.

31. Gries, Stefan. 2008. Phraseology and linguistic theory: a brief survey. In Sylviane Granger \& Fanny Meunier [eds.], Phraseology: An interdisciplinary perspective, 3-25. Amsterdam \& Philadelphia: John Benjamins.

32. Herbst, Thomas. 2015. Why construction grammar catches the worm and corpus data can drive you crazy: accounting for idiomatic and non-idiomatic idiomaticity. Journal of Social Sciences 11[3]. 91-110.

33. Hilpert, Martin. 2014. Construction Grammar and its Application to English. Cambridge: Cambridge University Press.

34. Hoey, Michael. 2005. Lexical priming: A new theory of words and language. London: Routledge.

35. Hoffmann, Sebastian, Bettina Fischer-Starcke \& Andrea Sand. 2015. Current Issues in Phraseology. Amsterdam \& Philadelphia: John Benjamins. 
36. Howarth, Peter A. [1996]. Phraseology in English academic writing: Some implications for language learning and dictionary making. Berlin \& New York: Mouton de Gruyter.

37. Hüning, Matthias \& Barbara Schlücker. 2015. Multi-word expressions. In Peter O. Müller, Ingeborg Ohnheiser, Susan Olsen \& Franz Rainer [eds.], Word-Formation: An international handbook of the languages of Europe, Vol. 1, 450-467. Berlin \& Boston: De Gruyter Mouton.

38. Hunston, Susan \& Geoff Thompson. 2006. System and corpus Two traditions with a common ground. In Geoff Thompson, Susan Hunston \& Charis Thompson [eds.], System and corpus: Exploring connections, 1-15. London: Equinox.

39. Hunston, Susan. 2007. Semantic Prosody Revisited. International Journal of Corpus Linguistics 12 [2]. 249-268.

40. Hunston, Susan. 2011. Corpus Approaches to evaluation: Phraseology and evaluative language. London: Routledge.

41. Jaki, Sylvia. 2014. Phraseological Substitutions in Newspaper Headlines: More than Meats the Eye. Amsterdam \& Philadelphia: John Benjamins.

42. Kesckes, Istvan. 2013. Intercultural Pragmatics. New York: Oxford University Press.

43. Kovshova, Maria. 2012. Lingvokul'turologicheskiy metod vo frazeologii: kody kul'tury. Moscow: LIBROKOM.

44. Kunin, Aleksandr. 1970. Angliyskaya frazeologiya. Moscow: Vysshaya shkola.

45. Langlotz, Andreas. 2006. Idiomatic creativity: A cognitive linguistic model of idiom-representation and idiom-variation in English. Amsterdam \& Philadelphia: John Benjamins.

46. Laso, Natalia J. \& Danica Salazar. 2013. Collocations, lexical bundles and SciE-Lex: A review of corpus research on multiword units of meaning. In Isabel Verdaguer, Natalia J. Laso \& Danica Salazar. Biomedical English: A corpus-based approach, 1-21. Amsterdam \& Philadelphia: John Benjamins.

47. Lee, Penny. 2007. Formulaic language in cultural perspective. In Paul Skandera [ed.], Phraseology and culture in English, 471497. Berlin \& New York: Mouton de Gruyter.

48. Levin, Magnus \& Hans Lindquist. 2013. Like I said again and again and over and over: On the ADV1 and ADV1 construction with adverbs of direction in English. International Journal of Corpus Linguistics 18 [1]. 7-34.

49. Manca, Elena. 2010. From phraseology to culture: Qualifying adjectives in the language of tourism. In Ute Römer \& Rainer Schulze [eds.], Patterns, meaningful units and specialized discourses, 105-122. Amsterdam \& Philadelphia: John Benjamins.

50. Mel'čuk, Igor. 2015. Clichés, an understudied subclass of phrasemes. Yearbook of Phraseology 6 [1]. 55-86.

51. Moon, Rosamund. 1998. Fixed expressions and idioms in English: A corpus-based approach. Oxford: Clarendon Press.

52. Naciscione, Anita. 2010. Stylistic use of phraseological units in discourse. Amsterdam \& Philadelphia: John Benjamins.

53. Nesselhauf, Nadja. 2004. What are collocations? In David J. Allerton,NadjaNesselhauf\&Paul Skandera [eds.], Phraseological Units. Basic Concepts and Their Application, 1-21. Basel: Schwabe.

54. Nesselhauf, Nadja. 2005. Collocations in a Learner Corpus. Amsterdam \& Philadelphia: John Benjamins.

55. Nunberg, Geoffrey, Ivan A. Sag \& Thomas Wasow. 1994
Idioms. Language 70 [3]. 491-538.

56. Partington, Allan, Alison Duguid \& Charlotte Taylor. 2013. Patterns and meanings in discourse: Theory and practice in corpus-assisted discourse studies. Amsterdam \& Philadelphia: John Benjamins.

57. Partington, Allan. 2014. Evaluative prosody. In Karin Aijmer \& Christoph Rühlemann [eds.], Corpus pragmatics: A handbook, 279-303. Cambridge: Cambridge University Press.

58. Perek, Florent. 2015. Argument structure in usage-based construction grammar. Amsterdam \& Philadelphia: John Benjamins.

59. Philip, Gill. 2011. Colouring Meaning: Collocation and connotation in figurative language. Amsterdam \& Philadelphia: John Benjamins.

60. Prodromou, Luke. 2007. Bumping into creative idiomaticity. English Today 23 [1]. 14-25.

61. Rodríguez Martín, Gustavo A. 2014. Canonical modified phraseological units: Analysis of the paradox. Yearbook of Phraseology 5 [1]. 3-24.

62. Schönefeld, Doris. 2013. Go mad - come true - run dry: Metaphorical motion, semantic preference[s] and deixis. Yearbook of the German Cognitive Linguistics Association. 1 [1]. 215-236.

63. Sinclair, John. 1991. Corpus, concordance, collocation. Oxford: Oxford University Press.

64. Siyanova-Chanturia, Anna \& Ron Martinez. 2014. The idiom principle revisited. Applied Linguistics. 36 [5]. 549-569.

65. Siyanova-Chanturia, Anna. 2015. On the 'holistic' nature of formulaic language. Corpus Linguistics and Linguistic Theory 11 [2]. 285-301.

66. Teliya, Veronika. 1996. Russkaja frazeologija: semanticheskij, pragmaticheskij $i$ lingvokulturologicheskij aspekty. Moscow: Jazyki russkoj kultury.

67. Tognini-Bonelli, Elena. 2001. Corpus linguistics at work. Amsterdam \& Philadelphia: John Benjamins.

68. Vasilenko, Anatolij. 2011. Aspekty semantiki frazeologizmov [na materiale russkogo i frantsuzskogo yazykov] [Doctoral dissertation]. Orel: Orel State University.

69. Vega Moreno, Rosa E. 2007. Creativity and convention: The pragmatics of everyday figurative speech. Amsterdam \& Philadelphia: John Benjamins.

70. Wierzbicka, Anna. 2009. Exploring English phraseology with two tools: NSM semantic methodology and Google. Journal of English Linguistics 37 [2]. 101-129.

71. Wood, David. 2015. Fundamentals of formulaic language: An introduction. London: Bloomsbury Academic.

72. Wray, Alison. 2002. Formulaic language and the lexicon. Cambridge: Cambridge University Press.

73. Wray, Alison. 2008. Formulaic Language: Pushing the Boundaries. New York: Oxford University Press.

74. Wulff, Stefanie. 2008. Rethinking Idiomaticity: A Usage-based Approach. London \& New York: Bloomsbury Academic.

75. Wulff, Stefanie. 2013. Words and Idioms. In Thomas Hoffmann \& Graeme Trousdale [eds.], Oxford handbook of construction grammar, 274-289. Oxford: Oxford University Press.

76. Zykova, Irina. 2014. Rol' konceptosfery kultury v formirovanii frazeologizmov kak kulturno-jazykovykh znakov [Doctoral dissertation]. Moscow: Russian Academy of Sciences.

\section{DICTIONARIES AND DATABASES}
77. Corpus of Contemporary
American English.
http://corpus.byu.edu/coca/
78. Brown, Keith \& Jim Miller. [Eds]. 2013. The Cambridge Dic- tionary of Linguistics. New York: Cambridge University Press.

\section{Finding the common ground: phraseological theory and terminology revisited \\ Ю. Ковалюк}

Abstract. Настоящая работа представляет собой обзор современной теории фразеологии. Известно, что область фразеологии имеет дело с «формульной природой языка, психолингвистической реальностью целостно запоминаемых многословных выражений и важностью фразеологических единиц при изучении второго языка» [Hoffmann et al. 2015: 1]. Тем не менее, существуют две основные проблемы: постоянно расширяющийся список терминов, относящихся к фразеологии, и множество подходов к ее описанию. С тем чтобы решить эти проблемы в настоящей статье основное внимание будет уделено двум основным подходам к изучению фразеологии: традиционному подходу и частотностному подходу. Затем будет проведен обзор фразеологической терминологии. Кроме того, будут продемонстрированы связи между фразеологией и четырьмя влиятельными дисциплинами: грамматикой конструкций, семантикой, прагматикой и лингвокультурологией. В конечном итоге будет осуществлено обсуждение затронутых в иссследовании вопросов.

Ключевые слова: фразеология, грамматика конструкций, семантика, прагматика, лингвокультурология. 